\title{
HUKUM ISLAM DAN MASLAHATNYA DI INDONESIA
}

\author{
Hasan H. Muhammad ${ }^{1}$ \\ Pengadilan Tinggi Agama Manado \\ hasan_47@yahoo.co.id
}

\begin{abstract}
Abstrak
Indonesia adalah Negara hukum dimana hukum Islam telah tertanam dihati masyarakat dan menjadi aturan dalam kehidupan sehari-hari. Pada awalnya Hukum Islam hanyalah diakui sebagai Hukum tak tertulis (unwritten law) atau disamakan dengan Hukum adat. Namun setelah proklamasi kemerdekaan RI diproklamirkan oleh Bung Karno dan Bung Hatta, Hukum islam setahap demi setahap meningkat ke posisi hukum tertulis. Belasan bahkan ratusan peraturan perundang-undangan telah dikeluarkan oleh pemerintah yang memperlakukan hukum islam kepada masyarakat. Proses taqninisasi hukum islam berjalan dengan baik bahkan secara khusus Propinsi Aceh Darussalam telah mengeluarkan qanun yang memperlakukan hukum Islam diberbagai daerah lainnya seperti Sulawesi Selatan, Kalimantan Selatan, Jawa Barat dan lain-lain bermunculan perda Syari'ah seperti; Perda Zakat, Perda Larangan Miras, Perda membaca Al-Quran dan lainlain yang mana telah nyata memberikan maslahat kepada masyarakat.
\end{abstract}

Kata Kunci: Hukum Islam, Hukum Tertulis, Maslahat.

Hasan H. Muhammad

\section{A. Pendahuluan}

\footnotetext{
${ }^{1}$ Dosen tidak tetap STAIN Manado / Ketua Pengadilan Tinggi Agama Propinsi Sulawesi Utara
} 
Disamping Negara hukum-hukum², Indonesia adalah juga Negara beragama yang biasa juga disebut dengan Negara berTuhan, atau Negara yang beketuhanan. Sebagai Negara hukum yang beragama, atau Negara yang menjunjung tinggi supremasi hukum, Indonesia sesuai dengan amar konstitusinya harus menghormati nilai-nilai agama ialah norma atau nilai hukum agama yang dalam agama Islam lazim diistilahkan dengan "hukum Islam”, "fikih Islam”, "hukum fikih", "hukum syara", "hukum syari'at", atau "syari'at Islam"3.

Seperti diketahui, berlainan dengan keberadaan hukum Islam dimasa-masa pemerintahan penjajah Belanda yang di posisikan kedalam hukum tidak tertulis bersama-sama hukum adat, maka eksistensi hukum islam bersama-sama hukum adat masih dimasih dianggap atau diposisikan sebagai hukum tidak tertulis (unwritten law). Keberadaan hukum Islam setelah proklamasi kemerdekaan Republik Indonesia terutama setelah dasawarsa 1970-an, beralih status atau kelas dari hukum tidak tertulis menjadi hukum tertulis yang tidak lain dan tidak bukan adalah peraturan perundang-undangan Negara Hukum Indonesia. Diawali dari sector hukum keluarga dengan pengundangan Undang-Undang Republik Indonesia No. 1 Tahun 1974 tentang Perkawinan, kemudian diikuti dengan Peraturan Pemerintah No. 9 Tahun 1975 tentang Pelaksanaan Undang-Undang Republik Indonesia No. 1 Tahun 1974 tentang Perkawinan dan khusus bagi umat Islam, dikeluarkan

Hukum Islam dan Mashlatnya.....

\footnotetext{
2 Pasal 1 ayat 3 Undang-Undang Dasar Negara Republik Indonesia Tahun 1945.

3 Keragaman sebutan atau istilah yang digunakan untuk menyebut hukum Islam, tidak sampai mengaburkan maksud dari penggunaan istilah Syari'at Islam di Indonesia.
} 
Instruksi Presiden Republik Indonesia No. 1 Tahun 1991 tentang Kompilasi Hukum Islam.

Sejak tahun 1970 hingga sekarang, pengundangan atau taqninisasi hukum Islam di Negara hukum Indonesia terus berjalan meskipun tidak jarang sesekali atau seringkali mengalami hambatan dan atau tantangan. Proses taqninisasi hukum Islam atau Islamisasi perundangan-undangan di Indonesia, antara lain dapat dibaca dan dipelajari dari deretan peraturan perundang-undangan sebagai berikut:

1. Undang-Undang Republik Indonesia No. 14 Tahun 1970 tentang PokokPokok Kekuasaan Kehakiman yang kemudian diubah dengan UndangUndang Republik Indonesia No. 35 Tahun 1999 tentang perubahan atas Undang-Undang Republik Indonesia No. 14 Tahun 1970 tentang Pokok-

Pokok Kekuasaan Kehakiman, kemudian diubah dengan Undang-Undang Republik Indonesia No. 4 Tahun 2004 dan perubahan terakhir dengan Undang-Undang Republik Indonesia No. 48 Tahun 2009 tentang Kekuasaan Kehakiman.

2. Undang-Undang Republik Indonesia No. 1 Tahun 1974 tentang Perkawinan.

3. Peraturan Pemerintah Republik Indonesia No. 9 Tahun 1975 tentang Pelaksanaan Undang-Undang Republik Indonesia No. 1 Tahun 1974 tentang Perkawinan.

4. Peraturan Pemerintah Republik Indonesia No. 28 Tahun 1977 tentang Perwakafan Tanah Milik.

5. Peraturan Menteri Dalam Negeri No. 6 Tahun 1977 tentang Tata Pendaftaran Tanah mengenai Perwafakan Tanah Milik.

6. Undang-Undang Republik Indonesia No. 14 Tahun 1985 tentang Mahkamah Agung yang kemudian diubah dengan Undang-Undang Republik Indonesia No. 5 Tahun 2004 dan perubahan terakhir dengan Undang Undang Republik Indonesia No. 3 Tahun 2009.

\section{Hasan H. Muhammad}


7. Undang-Undang Republik Indonesia No. 7 Tahun 1989 tentang Peradilan Agama, yang kemudian diubah dengan Undang-Undang Republik Indonesia No. 3 Tahun 2006 dan perubahan kedua dengan Undang-Undang Republik Indonesia No. 7 Tahun 1989 tentang Peradilan Agama.

8. Undang-Undang Republik Indonesia No. 2 Tahun 1989 tentang sistem Pendidikan Nasional, yang kemudian diubah dengan Undang-Undang Republik Indonesia No. 20 Tahun 2003.

9. Instruksi Presiden Republik Indonesia No. 1 Tahun 1991 tentang Kompilasi Hukum Islam.

10. Undang-Undang Republik Indonesia No. 23 Tahun 1992 tentang Kesehatan, yang mengubah Undang-Undang Republik Indonesia No. 9 Tahun 1960 tentang Pokok-Pokok Kesehatan.

11. Undang-Undang Republik Indonesia No. 7 Tahun 1992 tentang Perbankan, yang kemudian diubah dengan Undang-Undang Republik Indonesia No. 10 Tahun 1998 tentang perubahan atas Undang-Undang No. 7 Tahun 1992 tentang Perbankan.

12. Peraturan Pemerintah Republik Indonesia No. 72 Tahun 1992 tentang Bank Berdasarkan Prinsip Bagi Hasil.

13. Undang-Undang Republik Indonesia No. 8 Tahun 1999 tentang Perlindungan Konsumen.

14. Peraturan Pemerintah Republik Indonesia No. 69 Tahun 1999 tentang Label dan iklan Pangan.

15. Undang-Undang Republik Indonesia No. 17 Tahun 1999 tentang Penyelenggara Ibadah Haji.

16. Undang-Undang No. 38 Tahun 1999 tentang Pengolahan Zakat. 
17. Undang-Undang Republik Indonesia No. 18 Tahun 2001 tentang Otonomi Khusus bagi Propinsi Daerah Istimewa Aceh sebagai Propinsi Nangroe Aceh Darussalam.

18. Undang-Undang Republik Indonesia No. 24 Tahun 2004 tentang Lembaga Penjaminan Simpanan.

19. Undang-Undang Republik Indonesia No. 41 Tahun 2004 tentang Waqaf.

20. Undang-Undang Republik Indonesia No. 21 Tahun 2008 tentang Perbankan Syari'ah.

21. Undang-Undang Republik Indonesia No. 44 Tahun 2008 tentang Pornografi.

22. Undang-Undang Republik Indonesia No. 19 Tahun 2008 tentang Sukuk.

Sejumlah peraturan perundang-undangan lainnya yang minimal berhubungan atau bahkan menyatu ihwal hukum yang berhubungan dengan pelaksanaan prinsip-prinsip syariah atau hukum islam misalnya Surat Edaran Mahkamah Agung, Surat Keputusan Menteri Agama, Surat Keputusan Menteri Dalam Negeri, Menteri Keuangan, Peraturan Bank Indonesia dan lain-lain yang jumlahnya belasan bahkan ratusan dan dinyatakan berlaku dan diberlakukan diseluruh wilayah Negara hukum Indonesia.

\section{B. Pembebasan}

Dari belasan hingga ratusan peraturan perundang-undangan yang disebutkan diatas, dapatlah dipahami dan disimpulkan bahwa di Indonesia, proses taqninisasi hukum Islam telah berjalan bahkan secara khusus Propinsi Nangroe Aceh Darussalam telah menjadi Qanun yang khusus memberlakukan Syariat Islam di Propinsi Sulawesi Selatan, Kalimantan Selatan dan lain-lain ada juga mengeluarkan PERDA yang memberlakukan hukum Islam misalnya PERDA ZAKAT,

\section{Hasan H. Muhammad}


PERDA Larangan Miras, PERDA Penutupan rumah makan dibulan Ramadhan, PERDA Pelajaran membaca Al-Qur'an dan lain-lain.

Demikian pula dalam batas-batas tertentu berjalan pula proses Islamisasi peraturan perundang-undangan secara pelan dan sesungguhnya telah berjalan dalam waktu 30 sampai 40 -an tahun terakhir. Hal ini bisa terjadi antara lain disebabkan jaminan dan perlindungan Undang-Undang Dasar Republik Indonesia Tahun 1945 dalam menghormati nilai-nilai agama disamping berkat kepedulian pemerintah bersama-sama Dewan Perwakilan Rakyat merespon kebutuhan warga Negara.

Hal lain yang tidak kalah pentingnya ialah berkat keluwesan Hukum Islam yang selalu siap dan up to date untuk diposisikan ke dalam deretan sistem hukum yang manapun, baik ketika diposisikan sebagai hukum tidak tertulis dan lebihlebih ketika diposisikan sebagai hukum tertulis yang digalakkan oleh NegaraNegara modern sekarang.

Tentang fungsi Hukum Islam di Negara hukum Indonesia, selain Hukum Islam itu berfungsi sebagai salah satu bahan baku bersama-sama Hukum Adat dan hukum Barat, atas perintah atau instruksi undang-undang, Hukum Islam juga bisa langsung difungsikan sebagai hukum positif yang dinyatakan berlaku atau berlakukan di Negara hukum Indonesia. Sebagai contoh Peraturan Pemerintah No. 28 Tahun 1977 tentang Perwakafan Tanah Milik, Undang-Undang Republik Indonesia No. 7 Tahun 1989 Tentang Peradilan Agama yang telah diubah dengan Undang-Undang Republik Indonesia No. 3 Tahun 2006 dan perubahan kedua dengan Undang-Undang Republik Indonesia No. 50 Tahun 2009 tentang Peradilan Agama dan lain-lain.

\section{PERDA SYARIAH}


Setelah pelaksanaan otonomi daerah di resmikan pertama kali oleh pemerintah, yaitu pada bulan Januari 2001 dengan secara serta merta meluas aspirasi penerapan hukum Islam Syariah di daerah. Hal ini mengkristal dengan ide pembentukan lahirnya Peraturan Daerah yang bernafaskan hukum Islam atau Perda Syariah.

Ide pembentukan Perda Syariah terlihat pada dua bentuk:

a. Lewat otonomi daerah menjadi dasar bagi daerah untuk melahirkan PerdaPerda Syariah misalnya di Sulawesi Selatan, Kalimantan Selatan dan lainlain. Di Sulawesi Selatan telah dibentuk Komite Persiapan Penerapan Syariah Islam (KPPSI) dan komite inilah yang akan memperjuangkan formalisasi penerapan syariat Islam. Di samping itu telah semakin banyak pengajuan gerakkan KPPSI dan semakin gencar melakukan kegiatan-kegiatan seperti kongres di bulukumba yang dilaksanakan pada tanggal 26 - 28 Maret 2005. sebelumnya telah dua kali dilaksanakan kongre serupa. selain itu, puluhan bahkan ratusan artikel yang terbit di surat kabar, majalah dan internet yang di tulis untuk hal ini.

Untuk meningkatkan SDM mereka dalam hal penerapan hukum Islam pemerintah daerah mengirim tim studi komparatif penerapan syariat Islam ke berbagai negeri seperti Malasyia (Kuala Lumpur, Malaka, Terenggano).

b. Menjelang akhir tahun 2004 muncul Daerah Propinsi dan Kabupaten Kota yang ingin memperoleh otonomi khusus seperti halnya Nangroe Aceh Darussalam. Daerah yang paling gigih untuk hal ini adalah Sulawesi Selatan dan Kalimantan Selatan. Beberapa kabupaten seperti Bulukumba di Sulawesi Selatan, Banjarmasin dan Kandangan di Kalimantan Selatan, Cianjur dan Tasikmalaya di Jawa Barat, Propinsi Banten, Propinsi Sumatera Barat dan lain-lain telah mengeluarkan Perda Syariah (hukum islam) seperti Perda tentang minuman

\section{Hasan H. Muhammad}


Keras, Perda infak, zakat, sedekah pendidikan Al-Quran bagi siswa dan calon pengantin.

Tantangan terhadap munculnya Perda Syariah berdatangan dari beberapa pihak seperti Partai Damai Sejahtera berpendapat bahwa pemberlakuan Perda Syariah tidak boleh sama sekali karena dapat mengancam eksistensi NKRI yang dihuni oleh pluralitas agama, hal itu dipahami sebagai semangat menghidupkan kembali Piagam Jakarta.

PDS tampil dengan giat berkampanye melakukan penentangan terhadap Perda-Perda Syariah. Ketua PDS, Constan Ponggawa menunjukkan kegelisahan atas maraknya berbagai Perda Syariah dengan mendatangi wakil ketua DPR dan meminta pimpinan DPR menyurati presiden Soesilo Bambang Yudhoyono untuk mencabut perda tersebut ${ }^{4}$.

John. A. Tatulei dari Universitas Satya Wacana, Salatiga menyatakan: "Bagaimanapun, apa yang telah disepakati bersama oleh para pendiri bangsa ini adalah sebuah Negara yang plural, termasuk konsep keberagaman yang telah menciptakan keberadaan baru Indonesia. Telah terstigmatisasi oleh kenyataan yang ketika sebuah konstitusi dibuat oleh publik, kata Tuhan telah dihilangkan dalam paragraf ketiga Pembukaan UUD kita, namun kata Allah masih ada, ini adalah penghianatan pertama terhadap Negara Indonesia seperti telah terjadi sekarang ini di Indonesia masih sebuah Negara pancasila? ${ }^{5}$.

Menanggapi tantangan dan pertanyaan ini, dapat dijelaskan sebagai berikut:

Hukum Islam dan Mashlatnya.....

\footnotetext{
${ }^{4}$ Muhammad Ramadhan, dkk. Pergumulan Pemikiran Syariat Islam di Indonesia. (Majelis Alumi Fak. Syariah IAIN Sumatera Utara. Cipta pustaka Media, Bandung, 2007), h. 21

${ }^{5}$ Ibid. h. 24
} 
a. Pancasila dan UUd RI Tahun 1945 sebagai ideologi dan dasar Negara adalah sesuatu yang disepakati sampai saat ini, karenanya haruslah didukung dan dipertahankan. Mendukung dan mempertahankannya harus dalam posisi mendudukan kerangka berfikir dimana Negara yang kita cintai ini adalah milik seluruh komponen bangsa yang multi agama dan keyakinan kepada Tuhan Yang Maha Esa, karenanya harus memberikan hak yang sebesarbesarnya kepada seluruh umat beragama untuk mendapat tempat hidup dan berkreasi di Indonesia ini.

b. Sebagai amanat sila pertama pancasila dan pasal 29 UUD RI Tahun 1945, pemerintah harus memberikan sarana dan fasilitas bahkan dukungan yang seluas-luasnya kepada seluruh bangsa Indonesia untuk dapat menjalankan ajaran agama dan kepercayaannya masing-masing, sekaligus harus menyingkirkan setiap hal yang menjadi rintangan pemenuhan kebutuhan spritualitas tersebut. Pemberian pemerintah ini bisa bersifat finansial, material, konstitusional, political dan yang lainnya. Dengan demikian penganut umat beragama dapat secara layak menjalankan ajaran agamanya.

c. Dalam bentuk realitas, terlihat bahwa ajaran Islam memiliki dimensi dan aturan hukum yang lebih komprehensif dibandingkan seluruh agama lainnya di Indonesia. Bahwa Al-Quran adalah kitab suci umat Islam yang memberi pengaturan selengkap dan sedetail mungkin bersama Al-Hadis. Sementara pada kitab agama lain, hal itu tidak ditemukkan. Karenanya pemenuhan kebutuhan hukum Islam bagi umat Islam jauh lebih besar dibandingkan agama lain.

Berangkat dari tiga penjelasan tersebut, khusus menjawab persoalan umat Islam dengan perda syariahnya di beberapa daerah, penulis mengemukakan pendapat dua orang tokoh yaitu:

\section{Hasan H. Muhammad}


a. K. H. Abdurrahman Wahid dengan konsep pribumisasi Islam. Ini memberi bukti bahwa kita harus memantapkan Islam dibumi Indonesia ini. Islam harus dijadikan sebagai tatanan hidup masyarakat muslim meskipun Negara berada pada tempat yang netral, dan memang Negara harus tetap dalam kenetralannya.

Dalam pandangan ini, Islam dijadikan sebagai faktor komplementer kehidupan sosial, budaya dan politik bangsa Indonesia. Berhubung heterogenitasnya penduduk nusantara tidak berarti umat Islam tidak berhak mengisi kehidupan berbangsa dan bernegara dengan nilai ajaran agamanya. Mereka berhak melakukannya sebagaimana kelompok agama lainnya. Ia mengajak mempertimbangkan situasi lokal dalam menekuni ajaran islam agar tidak tercabut dari akar budayanya, tetapi dengan tetap mempertahankan ciri islam dalam bentuknya yang asli ${ }^{6}$.

b. Munawir Syazali dengan konsep reaktualisasi ajaran islamnya. Dia berpandangan bahwa bentuk dan dasar Negara kita ini telah sesuai dengan islam karena islam tidak menawarkan bentuk Negara sama sekali, yang penting ajaran Islam dapat tumbuh hidup dan berkembang, sekaligus diamalkan di Indonesia ${ }^{7}$.

Sesungguhnya lahirnya Perda Syariah yang keuntungannya menginventarisasikan substansi ajaran Islam bagi pemeluknya tidak perlu dipermasalahkan, karena jangan Perda Syariah, Undang-Undang yang bersifat nasional sudah banyak lahir sebelumnya. Undang-Undang No. 38 Tahun 1999 tentang pengelolaan zakat, Undang-Undang No. 7 Tahun 1989 tentang Peradilan Agama, Undang-Undang No. 41 Tahun 2004 tentang wakaf, Instruksi Presiden No. 1 Tahun 1991 tentang Kompilasi Huku Islam, Undang-

Hukum Islam dan Mashlatnya.....

${ }^{6}$ Ibid. h. 23.

${ }^{7}$ Ibid. h. 75 
Undang Penyelanggara Ibadah Haji, Undang-Undang No. 21 Tahun 2008 tentang Bank Syariah dan lain sebagainya.

Menurut Ramadhan, lahirnya Perda yang dilabelkan dengan "Perda Syariah" bukanlah dalam rangka ekslusifisme Islam, tetapi pemenuhan kebutuhan hukum agama mereka yang lebih besar penganutnya dari agama lain. Hal ini diibaratkan dengan perbandingan: Ada orang kampung yang biasanya setiap pagi harus makan nasi dalam porsi besar, dan dia bersahabat dengan orang kota yang terbiasa hanya minum secangkir teh dengan sepotong roti di pagi hari. Sewaktu mereka senantiasa bersama-sama, apakah mereka akan dipaksakan makan nasi dalam porsi yang banyak setiap pagi, atau hanya dengan meminum secngkir teh dan makan sepotong roti saja. Jawabannya, tentu tidak, justru yang adil adalah orang kampung harus tetap dibiarkan makan nasi sampai kenyang, dan orang kota pun minum teh dan sepotong roti saja. Pelabelan "Perda Syariah" sesungguhnya tidak ada hal baru didalamnya, karena secara substansi hal seperti itu sudah biasa di Indonesia ${ }^{8}$.

Perda Syariah dimungkinkan lahir dengan mempedomani pendapat Jimly Ash-Shiddiqie yang mengatakan: "Sebagai dampak dari kebijakan otonomi daerah yang seluas-luasnya bagi NAD, sekarang ini kita memang tetap mempedomani prinsip hukum lex superior derogant lex infiriore (secara hierarki, peraturan perundang-undangan yang tingkatannya dibawah tidak boleh bertentangan dengan peraturan yang tingkatannya lebih tinggi). Sepanjang kaitannya dengan hukum dalam sistem Negara yang tersentralisasi. Hal ini akan mandek dijalan karena adanya koridor hukum yang tegas yang berlaku secara nasional. Berbeda halnya dengan itu, dalam sistem desentralisasi yang dianut sekarang ini, dimana daerah ditentukan sebagai ujung tombak Pembangunan

\section{Hasan H. Muhammad}

\footnotetext{
${ }^{8}$ Ibid. h. 25
} 
Nasional, dan daerah di beri keleluasan untuk mengatur dirinya sendiri dalam porsi yang lebih besar, termasuk dalam melahirkan Perda Islam sesuai dengan kekhasan dan keistimewaan daerah tersebut karena sangat tepat memperbelakukan prinsip hukum lex specialis derogant lex generalis (peraturan khusus dapat mengenyampingkan berlakunya suatu peraturan yang bersifat umum). Daerah dapat saja memberlakukan Perda Syariah yang dibuatnya sendiri sepanjang dalam koridor kewenangan yang diberikan, meskipun dengan mengenyampingkan hukum yang bersifat umum dengan status hierarkis yang lebih tinggi. Dengan demikian NAD misalnya, boleh saja memberlakukan hukum cambuk dalam rangka mengamalkan Qanun, meskipun mengabaikan hukum penjara yang diatur dalam kitab Undang-Undang hukum Pidana (KUHP) sebagai tindak lanjut pelaksanaan peran otonomi daerah yang diamanatkan oleh Undang-Undang No. 18 Tahun $2001^{9}$.

\section{Maslahat}

Kepentingan publik atau masyarakat merupakan persoalan mendasar yang harus diperhatikan dalam menggali hukum Islam. Sebab tujuan pokok sang pembuat hukum (syari) tidaklah dimaksudkan kecuali untuk mewujudkan kemaslahatan untuk orang banyak, yaitu mendatangkan keuntungan bagi manusia dan menolak mudharat, atau menghilangkan keberatan.

Syariat Islam bukanlah bermaksud menempatkan manusia dalam penguasaan eksploitasi hukum agama, melainkan untuk menggambarkan kemaslahatan duniawi dan ukhrawi secara bersama. Demikian ungkapan sebagaimana dikutip Hamka Haq ${ }^{10}$.

\section{Hukum Islam dan Mashlatnya....}

\footnotetext{
${ }^{9} \mathrm{Ibid}$. h. 126

${ }^{10}$ Hamka haq. Filsafat Ushul Fikih (Makassar, Yayasan Al-Ahkam, 1998, h. 56-57.
} 
Untuk tujuan di atas, para ahli ushul sendiri telah memperkenalkan beberapa metode istinbat hukum setelah Al-Quran dan al-hadis sebagai sumber rujukan. Metode ini memberikan porsi akal secara lebih longgar. Metode-metode seperti istihsan, qiyas, dan sad al-dzara ' $I$, atau metode lainnya sudak cukup popular di kalangan ushuliyin yang semuanya di bangun atas pertimbangan maslahat.

Misi yang dibawa oleh agama Islam sendiri adalah untuk kemaslahatan manusia. Begitu pula ketentuan-ketentuan hukumnya, tidak bisa dilepaskan dari pertimbangan maslahat atau tidak.

Atas dasar inilah penulis mencoba mengkaji tentang maslahat sebagai tujuan utama hukum Islam dengan melihat perubahan dan perkembangan situasi dalam kondisi masyarakat tentunya. Dengan cara ini pula akan diketahui peluang maslahat sebagai pertimbangan dalam membangun hukum Islam dimasa sekarang, khususnya bagi Mahkamah Konstitusi dalam menguji undang-undang terhadap UUD Republik Indonesia Tahun 1945.

a. Pengertian Maslahat

Maslahat (al-maslahah bentuk pluralnya al-mashâlih) adalah mashdar (gerund) dari kata shalaha-yashlahu-shulûhan wa shalâh [an] yang berarti kebaikan / kelurusan. Secara bahasa artinya adalah lawan dari fasâd (kerusakan). Karena itu, ishlâh dan istislâh adalah lawan dari ifsâd dan istifâd; maslahat adalah lawan dari mafsadat. Di dalam mu 'jam al-Wasith dikatakan shalahah shalahan wa shulûh [an], artinya fasad (kerusakan) hilang darinya. Sesuatu yang bermanfaat dan sesuai dikatakan: yaslahu laka. Juga dinyatakan, maslahah adalah ash-shalâh dan manfaat ${ }^{11}$.

Abu al-'Abbas al-Fayyumi dalam Mishbâh al-Munîr fi Gharîb al-Syarh alKabîr mengatakan, " wa ashlahtuhu fa

\section{Hasan H. Muhammad}

\footnotetext{
${ }^{11}$ Ibrahim Anis dkk, Al-Mu jam al-Wasîth. (Kairo: t.tp., 1972). h.
} 
Shalaha wa ashlaha adalah membawa al-shalâh, yaitu kebaikan (al-khayr) dan yang benar / sesuai (al-shawâb). Di dalam perkara tersebut terdapat mashlahah, yaitu terdapat kebaikan (al-khayr $)^{12}$.

Dengan demikian, mashlahat secara bahasa dapat dimaknai sebagai manfaat, kebaikan dan jauh dari kerusakan. Jadi, maslahat itu meliputi salah satu dari dua sisi atau keduanya sekaligus, sisi mendatangkan manfaat atau kebaikan serta sisi menghilangkan / mencegah kerusakan (masfsadah) dan bahaya (madharah) - jalb al-manâfi' af al-khyr wa daf'u al-mafâsid aw almadharrah.

Secara terminology, terdapat beberapa definisi maslahat yang dikemukakan ulama ushul al-figh, tetapi seluruhnya mengandung esensi yang sama. Ibn Qudamah di dalam Rawdhah al-Nâzhir wa Jannah al-Munâzhir menyatakan, mashlahah adalah mendatangkan manfaat dan menolak bahaya (jalb al-manfa 'ah wa daf'u al madharrah). Sedangkan dalam al-Mustasyfa fi 'Ilm al-Ushul menurut Imam al-Ghazzali pada prinsipnya maslahat adalah mengambil manfaat dan menolak kemadharatan dalam rangka memelihara tujuan syara' ${ }^{\prime 3}$. Adapun dalam keputusan fatwa Majelis Ulama Indonesia pada tahun 2005m maslahat diartikan dengan "tercapainya tujuan syari'ah (maqashid al-Syari'ah) yang primer (al-daruriyyat al-khams), yaitu agama, akal, jiwa, harta dan keturunan"14.

b. Maslahat Sebagai Tujuan Utama Hukum Islam

Salah satu konsep penting dan fundamental yang menjadi pokok bahasan dalam filsafat hukum Islam adalam konsep

\section{Hukum Islam dan Mashlatnya....}

\footnotetext{
${ }^{12}$ Abu al-'Abbas al-Fayyumi, Misbâh al-Munir fi Garib al-Syarh al-Kabir, (Beirut: Dar al-Kutub al-Ilmiyyah), h. 23

13 Al-Ghazali, al-Mustasyfâ min Ilm al-Ushûl, (Kairo: al-Amiriyyah: 1412), h. 250.

$14 \mathrm{http} /$ mui.go.id.
} 
Maslahat (maqâsid syariah) ${ }^{15}$ yang menegaskan bahwa hukum Islam disyariatkan untuk mewujudukan dan memelihara maslahat umat manusia. Konsep ini telah diakui oleh para ulama dan oleh karena itu mereka memformulasikan suatu kaidah yang cukup populer 'di mana ada maslahat, disana terdapat hukum Allah'16. Teori maslahat disini menurut Masdar F. Mas'Udi sama dengan teori keadilan sosial dalam istilah filsafat hukum ${ }^{17}$.

Imam al-Haramain al-Juwaini dapat di katakana sebagai ahli teori (ulama ushul fikih) pertama yang menekankan pentingnya memahami maslahat dalam menetapkan hukum Islam. Ia secara tegas mengatakan bahwa seseorang tidak dapat dikatakan mampu menetapkan hukum dalam Islam, sebelum ia benar memahami benar tujuan Allah mengeluarkan perintah-perintah dan laranganlarangannya ${ }^{18}$.

Pemikir dan ahli teori hukum Islam berikutnya yang secara khusus membahas maslahat adalah Izzuddin bin Abd Salam dari kalangan Syafieyyah. Ia lebih banyak menekankan dan mengelaborasi konsep maslahat secara hakiki dalam bentuk menolah mafsadah dan menarik manfaat ${ }^{19}$. Lebih jauh lagi ia menjelaskan, bahwa taklif harus bermuara pada terwujudnya maslahat manusia, baik di dunia maupun di akhirat ${ }^{20}$.

\section{Hasan H. Muhammad}

\footnotetext{
${ }^{15}$ Istilah yang sepadan dengan maslahah adalah maqâsid syariah, karena penetapan hukum dalam Islam muaranya adalah maslahah itu sendiri.

${ }^{16}$ Muhammad Sa'id Ramdan al-Buti, Dawâbit al-Mashlahah fi al-Syariah al-Islamiyyah, (Beirut: Muassasah al-Risalah, 1977), h. 12.

17 Masdar F. Mas’Udi, "Meletakkan kembali Maslahah sebagai Acuan Syariah" dalam jurnal Ilmu dan Kebudayaan Ulumul Qur'an, (No. 3 Vol. Th 1995), h. 97

${ }^{18}$ Abd al-Malik Ibn Yusuf Abu Al-Ma'ali al Juwaini, Al-Burhan fi Ushul al-Fiqh, (Kairo: Dar al-Anshar, 1400 H), h. 295. t.t)., h. 9 .

19 Izzuddin Abd al-Salam, Qawaid al-Ahkam fi Mashalih al-Anam, (Kairo: al-Istiqamat,

${ }^{20}$ Ibid.
} 
Pembahasan tentang maslahat (maqashid syariah) secara khusus, sistematis dan jelas dilakukan al-Syatibi dari kalangan Malikiyyah. Dalam kitabnya al-Muwafaqat yang sangat fenomenal itu, ia telah mengahabiskan lebih kurang sepertiga pembahasannya mengenai maslahat. Ia secara tegas mengatakan bahwa tujuan utama Allah menetapkan hukum-hukum-Nya adalah untuk terwujudnya maslahat hidup manusia, baik dunia maupun di akhirat. Karena itu taklif dalam bidang hukum harus mengarah pada dan merealisasikan terwujudnya tujuan hukum tersebut ${ }^{21}$.

Mengacu kepada kepentingan dan kualitas kemaslahatan itu, ia mengklasifikasikan as-mashlahah itu kepada tiga jenis ${ }^{22}$, sebagaimana juga dirumuskan secara general oleh para ahli hukum Islam lain.

Pertama, mashlahah dharuriyah, yaitu kemaslahatan yang sangat dibutuhkan dalam kehidupan manusia di dunia dan di akhirat (primer). Kemaslahatan ini berkaitan dengan lima kebutuhan pokok, yang disebut dengan al-mashalih al-khamsah, yaitu (1) memelihara agama, (2) memelihara jiwa, (3) memelihara akal, (4) memelihara keturunan, dan (5) memelihara harta.

Segala sesuatu yang tidak sesuai dengan kelima unsur pokok di atas adalah bertentangan dengan tujuan syara'. Karena itu, tindakkan tersebut dilarang tegas dalam agama. Allah melarang murtad demi untuk memelihara agama, membunuh dilarang untuk memelihara jiwa, minum-minuman keras dilarang untuk memelihara akal sehat, berzina diharamkan untuk memelihara keturunan, dan mencuri atau merampok dilarang untuk memelihara kepemilikkan terhadap harta.

\section{Hukum Islam dan Mashlatnya....}

${ }^{21}$ Al-Syátibi, al-Muwafaqat fi Usûl al-Syariah, (Kairo: Mustafa Muhammad, t.t), jilid II., h. 4 . ${ }^{22}$ Ibid. h. 5 . 
Kedua, maslahah hajiyah, yaitu kemaslahatan yang keberadaannya dibutuhkan dalam menyempurnakan lima kemaslahatan pokok tersebut yang berupa keringanan demi untuk mempertahankan dan memelihara kebutuhan dasar (basic need) manusia. Misalnya, rukhshah berupa kebolehan berbuka puasa bagi orang yang sedang musafir, kebutuhan makan untuk mempertahankan kelangsungan hidup, menuntut ilmu untuk mengasah otak dan akal, berniaga untuk mendapatkan harta. Semua ini di syari'atkan untuk mendukung pelaksanaan kebutuhan lima pokok tersebut.

Ketiga, maslahah tahsiniyyah, yaitu kemaslahatan yang bersifat pelengkap (komplementer) berupa keleluasaan yang dapat memberikan nilai plus bagi kemaslahatan sebelumnya (tertier). Kebutuhan dalam konteks ini perlu dipenuhi dalam rengka memberi kesempurnaan dan keindahan bagi hidup manusia. Umpamanya, dianjurkan memakan yang bergizi, berpakaian yang rapi, melaksanakan ibadah-ibadah sunat dan lain sebagainya ${ }^{23}$.

Konsep maslahat yang dikembangkan al-Syatibi di atas sebenarya telah melampaui pembahasan ulam-ulama abad sebelumnya. Konsep maslahat alSyatibi tersebut mencakup seluruh bagian syariah dan bukan hanya aspek yang tidak diatur oleh nash. Sesuai dengan pernyataan al-Ghazzalim, al-Syatibi menrangkum bahwa tujuan Allah menurunkan syariah adalah untuk mewujudkan maslahat. Meskipun begitu, pemikiran maslahat al-Syatibi ini tidak seradikal24 gagasan al-Tufi.

\section{Hasan H. Muhammad}

\footnotetext{
${ }^{23}$ Abdul Wahhab Khalaf, Usûl Fiqh, (Jakarta: Majelis al-A 'la al-Indunisy li al-Da 'wah al Islamiyah, 1972), h. 199. Baca juga Asywadie Syukur, Pengantar Ilmu Fikih dan Ushul Fikih, (Surabaya: Bina Ilmu, 1990), h. 227.

${ }^{24}$ Nur A. Fadhil Lubis, Hukum Islam dalam kerangka Teori Fikih dan Tata Hukum Indonesia, (Medan: Pustaka Widyasarana, 1995), h. 34-35.
} 


\section{c. Kesimpulan}

Dengan demikian, jelas bahwa yang fundamental dari bangunan pemikiran hukum Islam adalah maslahat, maslahat manusia yang universal atau dalam ungkapan yang lebih operasional "keadilan sosial". Tawaran teoritis (ijtihady) apapun dan bagaimanapun, baik di dukung dengan nash ataupun tidak, yang bisa menjamin terwujudnya maslahat kemanusiaan, dalam kacamata Islam adalah sah, dan umat Islam terkait untuk mengambilnya dan merealisasikannya. Sebaliknya, tawaran teoritis apapun dan bagaimanapun, yang secara meyakinkan dan tidak mendukung terjaminnya maslahat, lebihlebih yang membuka kemungkinan terjadinya kemudaratan, dalam kacamata Islam, adalah fasid, dan umat Islam sebagai orang perorang atau bersama-sama berkewajiban menolaknya.

Seyogyanya, hukum haruslah didasarkan pada sesuatu yang harus tidak disebut hukum, tetapi lebih mendasar dari hukum, tetapi lebih mendasar dari hukum. Yaitu, sebuah sistem nilai yang dengan sadar dianut sebagai keyakinan yang harus diperjuangkan, yaitu: maslahah (keadilan). Wallahu a'lam bi al sawab. 


\section{Daftar Pustaka}

Abdullah, Abdul Gani, 1994, Pengantar Kompilasi Hukum Islam dalam Tata Hukum Indonesia, Cet. I; Jakarta: Gema Insasi Press.

Ali, Achmad, 1998, Menjelajahi Kajian Empiris Terhadap Hukkum, Cet. I, Jakarta: Yarsif Watampone.

-------, 2002, Menguak Tabir Hukum (Suatu Kajian Filosofis dan Sosiologis). Jakarta, Toko Gunung Agung.

Ali, Muhhammad Daud, 1994, "Hukum Islam: Peradilan Agama dan Masalahnya" dalam Eddi Rudiana Arief dkk., Hukum Islam di Indonesia Pemikiran dan Praktek. Cet. II, Bandung: PT Remaja Rosdakarya.

-------, 1996, Hukum Islam: Pengantar Ilmu Hukum dan Tata Hukum Islam di Indonesia. Cet. I, Jakarta: PT Raja Grafindo Persada.

Alim, Muhammad, 2010 Asas-Asas Negara Hukum Modern dalam Islam (Kajian Komprehensif Islam dan Ketanegaraan). Cet. I; Yogyakarta: PT LkiS Printing Cemerlang.

Amin Suma, Muhammad, 2004, Himpunan Undang-Undang Islam dan Pelaksanaannya di Negara Hukum Indonesia. Cet II, Jakarta: Rajawali Pers. Ash-Shiddiqy, Jimly, 2006, Hukum Konstitusi dan Mahkamah Konstitusi, Jakarta: Sekertariat Jenderal dan Kepaniteraan Mahkamah Konstitusi, RI.

Azizy, Qodri, 2003, Reformasi Bermazhab: Sebuah Ikhtiar Menuju Ijtihad Sesuai Saintifik-Modern, Cet. I, Jakarta: Teraju.

\section{Hasan H. Muhammad}


'Azzam, Abd al-'Aziz Muhammad, 2005, Al-Qawa'id Al-Fiqhiyah, Kairo, Dar Al-Hadis.

Fachruddin, Fuad Mohd, 1966, Filsafat dan Hikmat Syari'at Islam. Cet. II, Djakarta : Bulan Bintang.

Fanani, Muhyar, 2008, Membumikan Hukum Langit: Nasionalisasi Hukum Islam dan Islamisasi Hukum Nasional Pasca Reformasi Cet. I, Yogyakarta: Tiara Wacana

Ichtijanto, 1994, "Perkembangan Teori Berlakunya Hukum Islam di Indonesia" dalam Eddi Rudiana Arief dll., Hukum Islam di Indonesia Perkembangan dan Pembentukkan, Cet. II. Bandung: PT Remaja Rosdakarya. 